\title{
PENGARUH PERBEDAAN KADAR KALSIUM HIDROKSIDA DAN PENAMBAHAN AIR TERHADAP KOMPOSISI KIMIA DAN KECERNAAN IN VITRO DAUN KELAPA SAWIT
}

\section{THE EFFECTS OF DIFFERENT LEVELS OF CALCIUM HYDROXIDE AND WATER ADDITION FOR CRUDE PALM LEAVES FERMENTATION ON ITS CHEMICAL COMPOSITION AND IN VITRO DIGESTIBILITY}

\author{
Ria Anjalani*, Subur Priyono Sasmito Budhi, dan Hari Hartadi \\ Fakultas Peternakan, Universitas Gadjah Mada, Jl. Fauna No. 3, Bulaksumur, Yogyakarta 55281
}

\section{INTISARI}

Penelitian ini bertujuan untuk mengetahui pengaruh perbedaan kadar kalsium hidroksida $\left(\mathrm{Ca}(\mathrm{OH})_{2}\right)$ dan air yang ditambahkan pada proses pemeraman daun kelapa sawit terhadap komposisi kimia dan kecernaan secara in vitro. Level kalsium hidroksida $\left(\mathrm{Ca}(\mathrm{OH})_{2}\right)$ yang digunakan untuk pemeraman dalam penelitian ini adalah 0,3 , dan $6 \%(\mathrm{~b} / \mathrm{b})$, dengan kadar air daun kelapa sawit 40, 50, dan 60\% (b/b). Penelitian menggunakan Rancangan Acak Lengkap pola faktorial $3 \mathrm{x}$ 3. Masing-masing perlakuan diberikan ulangan 3 kali. Data hasil penelitian yang berbeda nyata diuji lanjut dengan Duncan's new Multiple Range Test. Hasil penelitian menunjukkan kisaran kandungan bahan kering (BK), bahan organik (BO), protein kasar (PK), serat kasar (SK), lemak kasar (LK), bahan ekstrak tanpa nitrogen (BETN), neutral detergent fiber (NDF), dan acid detergent fiber (ADF) berturut-turut sebesar 37,89-59,52\%, 87,83-92,96\%, 8,32-9,84\%, $35,91-40,63 \%, 5,98-7,47 \%, 34,66-40,06 \%, 64,74-75,39 \%$, dan 46,56-59,32\%. KcBK dan KcBO daun kelapa sawit sebesar 19,26-29,55\% dan 19,91-28,26\%. Perlakuan level kadar air dan $\mathrm{Ca}(\mathrm{OH})_{2}$ masing-masing mempengaruhi komposisi kimia daun kelapa sawit, tetapi tidak berpengaruh pada kecernaan. Kurang efektifnya perlakuan tunggal $\mathrm{Ca}(\mathrm{OH})_{2}$, waktu perlakuan yang singkat, dan level yang rendah menyebabkan efektivtas perlakuan $\mathrm{Ca}(\mathrm{OH})_{2}$ pada daun kelapa sawit masih rendah. $\mathrm{Ca}(\mathrm{OH})_{2}$ dengan level $6 \%$ dan kadar air $40 \%$ menunjukkan hasil terbaik pada penelitian ini.

(Kata kunci: Daun kelapa sawit, $\mathrm{Ca}(\mathrm{OH})_{2}$, Kadar air, Kecernaan in vitro)

\section{ABSTRACT}

This study was conducted to observe the effects of calcium hydroxide $\left(\mathrm{Ca}(\mathrm{OH})_{2}\right)$ and moisture level of soaked crude palm leaves on its chemical composition and in vitro digestibility. Level of $\mathrm{Ca}(\mathrm{OH})_{2}$ which used and moisture content which added for soaking process in this study were 0, 3, 6\% (w/w) and 40, 50, 60\% (w/w), respectively, on DM basis. This study was arranged in Complete Randomized Design using $3 \times 3$ factorial arrangements, with 3 replications. All significant results were then analysed with Duncan's new Multiple Range Test. After treatment, oil palm leaves were placed in polyethylene plastic bag and stored for 21 days. Result showed the DM, OM, CP, CF, EE, NFE, NDF and ADF of palm leaves after treated were 37.89-59.52\%, 87.83-92.96\%, 8.32-9.84\%, 35.91-40.63\%, 5.98-7.47\%, 34.6640.06\%, 64.74-75.39\% and 46.56-59.32\%, respectively. The IVDMD and IVOMD of palm leaves were 19.26-29.55\% and 19.91-28.26\%. Level of $\mathrm{Ca}(\mathrm{OH})_{2}$ and moisture content affected the chemical composition of palm leaves, but have no effect on its digestibility. The less effectiveness of $\mathrm{Ca}(\mathrm{OH})_{2}$ as a single treatment, caused by the low level of $\mathrm{Ca}(\mathrm{OH})_{2}$ and short time of treatment periode on palm leaves. $\mathrm{Ca}(\mathrm{OH})_{2}$ level of $6 \%$ and $40 \%$ moisture content was given the best results in this study.

(Key words: Crude palm leaves, $\mathrm{Ca}(\mathrm{OH})_{2}$, Moisture content, In vitro digestibility)

\section{Pendahuluan}

Perlakuan kimia pada pakan berserat tinggi bertujuan untuk meningkatkan pendegradasian dinding sel (selulosa dan hemiselulosa) oleh enzim yang dihasilkan oleh mikrobia dan memecah atau melonggarkan ikatan lignoselulosa dan lignohemiselulosa. Ada tiga macam bahan kimia yang dapat dimanfaatkan, yaitu: yang bersifat alkali (seperti: $\mathrm{KOH}, \mathrm{NaOH}, \mathrm{Ca}(\mathrm{OH})_{2}$, dan urea), bersifat

\footnotetext{
* Korespondensi (corresponding author):

Telp. +6281251561313

E-mail: riaanjalani@yahoo.com
}

asam (seperti: $\mathrm{H}_{2} \mathrm{~S}, \mathrm{HCl}$, dan $\mathrm{H}_{2} \mathrm{SO}_{4}$ ), dan senyawa oksidatif (seperti: $\mathrm{NaOCl}$ dan $\mathrm{H}_{2} \mathrm{O}_{2}$ ) (Soejono, 1992; Granzin dan Dryden, 2003). Kalsium hidroksida $\left(\mathrm{Ca}\left(\mathrm{OH}_{2}\right)\right.$ adalah salah satu bahan kimia yang dapat digunakan untuk meningkatkan kualitas bahan pakan berserat tinggi yang aman bagi lingkungan dan residunya dapat digunakan kembali oleh ternak.

Beberapa penelitian telah dilakukan untuk mengetahui pengaruh $\mathrm{Ca}(\mathrm{OH})_{2}$ terhadap beberapa bahan pakan berserat tinggi (roughages), dengan jenis dan kadar air bahan pakan, bentuk dan level $\mathrm{Ca}(\mathrm{OH})_{2}$, serta lama dan metode perlakuan yang berbeda. Namun, penelitian untuk meningkatkan 
kualitas daun kelapa sawit melalui proses fermentasi dengan menggunakan $\mathrm{Ca}(\mathrm{OH})_{2}$ belum dilakukan sehingga pengaruh perlakuan $\mathrm{Ca}(\mathrm{OH})_{2}$ terhadap komposisi dan kecernaan daun kelapa sawit belum diketahui. Penelitian ini bertujuan untuk mengetahui pengaruh perbedaan level $\mathrm{Ca}(\mathrm{OH})_{2}$ dan kadar air bahan pada komposisi kimia dan kecernaan in vitro dengan menggunakan cairan rumen sapi PO pada daun kelapa sawit.

\section{Materi dan Metode}

\section{Persiapan bahan dan alat}

Daun kelapa sawit yang digunakan diambil dari tanaman kelapa sawit varietas lonsum yang telah berumur 12 tahun yang diperoleh dari PT. Windu Nabatindo Lestari, Kabupaten Kotawaringin Timur, Provinsi Kalimantan Tengah. Daun kelapa sawit terlebih dahulu dianalisis komposisi kimia, serat, dan kecernaannya sebelum diberi perlakuan.

\section{Penambahan $\mathrm{Ca}(\mathrm{OH})_{2}$ dan air pada daun kelapa sawit}

Penelitian ini dilakukan dengan menambahkan $\mathrm{Ca}(\mathrm{OH})_{2}$ dan air dengan kadar yang berbeda. Penambahan $\mathrm{Ca}(\mathrm{OH})_{2}$ berdasarkan $D M$ basis pada daun kelapa sawit dengan level 0, 3, dan 6\% (b/b). Kadar air daun kelapa sawit yang digunakan adalah 40, 50, dan $60 \%(\mathrm{~b} / \mathrm{b})$. Terdapat 9 perlakuan pada penelitian ini, yaitu I (kadar air $40 \%+\mathrm{Ca}(\mathrm{OH})_{2}$ $0 \%$ ), II (kadar air $50 \%+\mathrm{Ca}(\mathrm{OH})_{2} 0 \%$ ), III (kadar air $60 \%+\mathrm{Ca}(\mathrm{OH})_{2} 0 \%$ ), IV (kadar air $40 \%+$ $\left.\mathrm{Ca}(\mathrm{OH})_{2} 3 \%\right), \mathrm{V}$ (kadar air $50 \%+\mathrm{Ca}(\mathrm{OH})_{2} 3 \%$ ), VI (kadar air 60\% $+\mathrm{Ca}(\mathrm{OH})_{2} 3 \%$ ), VII (kadar air 40\% $+\mathrm{Ca}(\mathrm{OH})_{2} 6 \%$ ), VIII (kadar air $50 \%+\mathrm{Ca}(\mathrm{OH})_{2}$ $6 \%$ ), dan IX (kadar air 60\% $+\mathrm{Ca}(\mathrm{OH})_{2} 6 \%$ ). Setiap faktor perlakukan diberikan replikasi 3 kali.

Daun kelapa sawit dipotong-potong dengan panjang sekitar $3 \mathrm{~cm}$ lalu ditimbang seberat 1188,45 $\mathrm{g}$ untuk masing-masing perlakuan. Selanjutnya, $\mathrm{Ca}(\mathrm{OH})_{2}$ ditambahkan sebanyak $31,5 \mathrm{~g}$ untuk level $3 \%$ dan $63 \mathrm{~g}$ untuk level 6\%. Aquades ditambahkan untuk melarutkan $\mathrm{Ca}(\mathrm{OH})_{2}$ sebanyak $561,55 \mathrm{ml}$ untuk kadar air 40\%, 911,55 ml untuk kadar air $50 \%$, dan 1.436,55 ml untuk kadar air $60 \%$. Larutan $\mathrm{Ca}(\mathrm{OH})_{2}$ dipercikkan pada daun kelapa sawit dan dicampur merata. Daun kelapa sawit kemudian ditempatkan di dalam kantong plastik polyethylene kedap udara lalu disimpan selama 21 hari dan diletakkan di tempat teduh.

Setelah penyimpanan 21 hari, daun kelapa sawit dikeringkan dalam oven $55^{\circ} \mathrm{C}$ selama 2 hari sampai beratnya konstan. Sampel daun sawit lalu digiling menggunakan wiley mill dengan diameter lubang saringan $2 \mathrm{~mm}$. Sampel tersebut kemudian digunakan untuk penetapan komposisi kimia meliputi bahan kering, bahan organik, protein kasar, lemak kasar, serat kasar, dan bahan ekstrak tanpa nitrogen (AOAC, 2005), komposisi serat meliputi neutral detergent fiber dan acid detergent fiber (Van Soest, 1994), serta kecernaan in vitro (Harris, 1970).

\section{Uji kecernaan in vitro 2 tahap}

Pengukuran kecernaan in vitro daun kelapa sawit menggunakan metode 2 tahap Tilley dan Terry yang dimodifikasi oleh Utomo (2010). Variabel kecernaan yang diamati meliputi kecernaan bahan kering (KcBK) dan kecernaan bahan organik (KcBO).

\section{Analisis data}

Data yang diperoleh dianalisis variansi menggunakan Complete Randomized Design dengan pola faktorial $3 \times 3$. Apabila terdapat perbedaan antara perlakuan diuji lanjut dengan Duncan's new Multiple Range Test (DMRT) (Steel dan Torrie, 1993).

\section{Hasil dan Pembahasan}

\section{Komposisi kimia dan kecernaan sebelum perlakuan}

Data yang meliputi komposisi kimia, serat, dan berat bahan segar sebelum dan setelah daun kelapa sawit diberi perlakuan diamati dalam penelitian ini. Data komposisi kimia, kandungan serat kasar, dan kecernaan in vitro daun sawit sebelum diberi perlakuan disajikan pada Tabel 1 .

Berat bahan segar dan $\mathbf{p H}$. Rerata berat bahan segar daun kelapa sawit sebelum dan sesudah penyimpanan selama 21 hari disajikan pada Tabel 2. Setelah daun kelapa sawit diberi perlakuan dan disimpan selama 21 hari, terjadi pengurangan berat bahan segar daun kelapa sawit. Perubahan ini menunjukkan bahwa terdapat aktivitas bakteri dan jamur selama penyimpanan yang memanfaatkan bahan organik di dalam daun kelapa sawit untuk pertumbuhannya.

Rerata $\mathrm{pH}$ daun kelapa sawit sebelum dan sesudah penyimpanan tersaji pada Tabel 3 . Terjadi penurunan $\mathrm{pH}$ daun kelapa sawit setelah perlakuan. Hal ini disebabkan karena adanya aktivitas bakteri selama proses penyimpanan yang memproduksi asam-asam organik sehingga $\mathrm{pH}$ daun pun turun. Tetapi, $\mathrm{pH}$ pada level $\mathrm{Ca}(\mathrm{OH})_{2} 3$ dan $6 \%$ tidak serendah pada level $0 \%$. $\mathrm{Ca}(\mathrm{OH})_{2}$ bersifat alkali sehingga memberikan suasana basa pada saat penyimpanan dan menyebabkan asam-asam organik yang terbentuk selama penyimpanan ternetralkan oleh $\mathrm{Ca}(\mathrm{OH})_{2}$ dan $\mathrm{pH}$ daun kelapa sawit pun masih dalam kondisi yang cenderung netral yaitu berkisar antara 6,43-7,27. Owen et al. (1984) menyatakan bahwa $\mathrm{Ca}(\mathrm{OH})_{2}$ berperan sebagai buffer pada proses fermentasi bahan pakan dengan perlakuan $\mathrm{Ca}(\mathrm{OH})_{2}$, sehingga asam-asam organik yang 
Tabel 1. Komposisi kimia, kandungan serat kasar, dan kecernaan in vitro daun kelapa sawit (\%BK) (chemical composition, crude fiber content and in vitro digestibility of crude palm leaves (\% of DM))

\begin{tabular}{lc}
\hline \hline \multicolumn{1}{c}{ Komposisi (composition) } & Kandungan (\%) (content (\%)) \\
\hline Bahan kering (dry matter) & 46,54 \\
Bahan organik (organic matter) & 94,71 \\
Protein kasar (crude protein) & 7,09 \\
Serat kasar (crude fiber) & 50,39 \\
Lemak kasar (extract ether) & 2,91 \\
Bahan ekstrak tanpa nitrogen (nitrogen free extract) & 34,32 \\
Neutral detergent fiber (NDF) & 68,46 \\
Acid detergent fiber (ADF) & 47,88 \\
Kecernaan (digestibility) & \\
$\quad$ Bahan kering (dry matter) & 26,89 \\
$\quad$ Bahan organik (organic matter) & 26,23 \\
\hline
\end{tabular}

Tabel 2. Rerata berat bahan segar daun kelapa sawit sebelum dan sesudah perlakuan (kg BK) (average fresh weight of crude palm leaves before and after treatment $(\mathrm{kg} \mathrm{DM})$ )

\begin{tabular}{|c|c|c|c|c|c|c|c|c|}
\hline \multirow{3}{*}{$\begin{array}{c}\text { Kadar air }(\%)(\text { moisture } \\
\text { content }(\%))\end{array}$} & \multicolumn{6}{|c|}{$\mathrm{Ca}(\mathrm{OH})_{2}(\%)$} & \multirow{2}{*}{\multicolumn{2}{|c|}{$\operatorname{Rerata}^{\text {ns }}$ (average) }} \\
\hline & \multicolumn{2}{|c|}{0} & \multicolumn{2}{|c|}{3} & \multicolumn{2}{|c|}{6} & & \\
\hline & $\begin{array}{c}\text { Aw } \\
\text { Before }\end{array}$ & $\begin{array}{c}\mathrm{Ak} \\
\text { After }\end{array}$ & $\begin{array}{c}\text { Aw } \\
\text { Before }\end{array}$ & $\begin{array}{c}\text { Ak } \\
\text { After }\end{array}$ & $\begin{array}{c}\text { Aw } \\
\text { Before }\end{array}$ & $\begin{array}{c}\text { Ak } \\
\text { After }\end{array}$ & $\begin{array}{c}\text { Aw } \\
\text { Before }\end{array}$ & $\begin{array}{c}\text { Ak } \\
\text { After }\end{array}$ \\
\hline 40 & 1,011 & 0,961 & 1,006 & 0,970 & 1,037 & 1,027 & 1,018 & 0,986 \\
\hline 50 & 1,009 & 0,961 & 1,017 & 0,993 & 1,028 & 1,010 & 1,018 & 0,988 \\
\hline 60 & 1,010 & 0,922 & 1,003 & 0,983 & 1,018 & 1,005 & 1,010 & 0,970 \\
\hline Rerata (average) & $1,010^{\mathrm{x}}$ & $0,948^{\mathrm{x}}$ & $1,009^{\mathrm{x}}$ & $0,982^{\mathrm{y}}$ & $1,028^{\mathrm{y}}$ & $1,014^{\mathrm{z}}$ & 1,015 & 0,981 \\
\hline
\end{tabular}

Aw : berat awal sebelum peram (initial weight before fermentation).

Ak: berat akhir sesudah peram (ultimate weight after fermentation).

diproduksi selama proses fermentasi akan ternetralkan.

Komposisi kimia setelah perlakuan. Komposisi kimia dan serat daun kelapa sawit setelah perlakuan tersaji pada Tabel 4. Pada tabel 4 terlihat perubahan pada komposisi kimia dan serat daun kelapa sawit akibat perlakuan yang diberikan.

Kandungan BK daun kelapa sawit setelah diberi perlakuan meningkat dengan meningkatnya level pemberian $\mathrm{Ca}(\mathrm{OH})_{2}$ dan menurun seiring dengan meningkatnya kadar air bahan. Penurunan kadar BK daun kelapa sawit pada level kadar air yang berbeda disebabkan karena terdapatnya penambahan air pada saat awal perlakuan. Adapun peningkatan kadar $\mathrm{BK}$ pada level $\mathrm{Ca}(\mathrm{OH})_{2}$ yang berbeda disebabkan oleh penambahan $\mathrm{Ca}(\mathrm{OH})_{2}$ yang secara langsung akan mempengaruhi BK daun kelapa sawit.

Kandungan BO daun kelapa sawit setelah diberi perlakuan mengalami penurunan seiring dengan pemberian $\mathrm{Ca}(\mathrm{OH})_{2}$ dan kadar air. Penurunan akibat peningkatan level $\mathrm{Ca}(\mathrm{OH})_{2}$ dan kadar air disebabkan karena naiknya kadar abu sebagai konsekuensi dari penambahan $\mathrm{Ca}(\mathrm{OH})_{2}$ pada daun kelapa sawit, terdapatnya BO yang terlarut bersama air tirisan akibat penambahan aquades di awal perlakuan, adanya pemanfaatan BO oleh bakteri dan jamur untuk pertumbuhan selama penyimpanan, dan menguap akibat pemanasan saat preparasi untuk sampel analisis.

Kandungan PK daun kelapa sawit mengalami peningkatan seiring dengan meningkatnya level $\mathrm{Ca}(\mathrm{OH})_{2}$. Dibanding dengan kondisi daun kelapa sawit tanpa perlakuan, terjadi kenaikan kandungan PK daun kelapa sawit setelah diberi perlakuan. Hal ini dikarenakan adanya komposisi lain yang berkurang akibat perlakuan yang diberikan dan menyebabkan naiknya persentase kandungan PK.

Penurunan kandungan SK daun kelapa sawit setelah diberi perlakuan menunjukkan bahwa $\mathrm{Ca}(\mathrm{OH})_{2}$ melepaskan ikatan lignoselulolusa atau lignohemiselulosa pada daun kelapa sawit yang diberi perlakuan. Adapun peningkatan LK daun kelapa sawit setelah diberi perlakuan disebabkan karena adanya penurunan dari karbohidrat yang terlarut dalam air (water soluble carbohydrates) 
Tabel 3. Rerata $\mathrm{pH}$ daun kelapa sawit sebelum dan sesudah perlakuan (average $\mathrm{pH}$ of crude palm leaves before and after treatment)

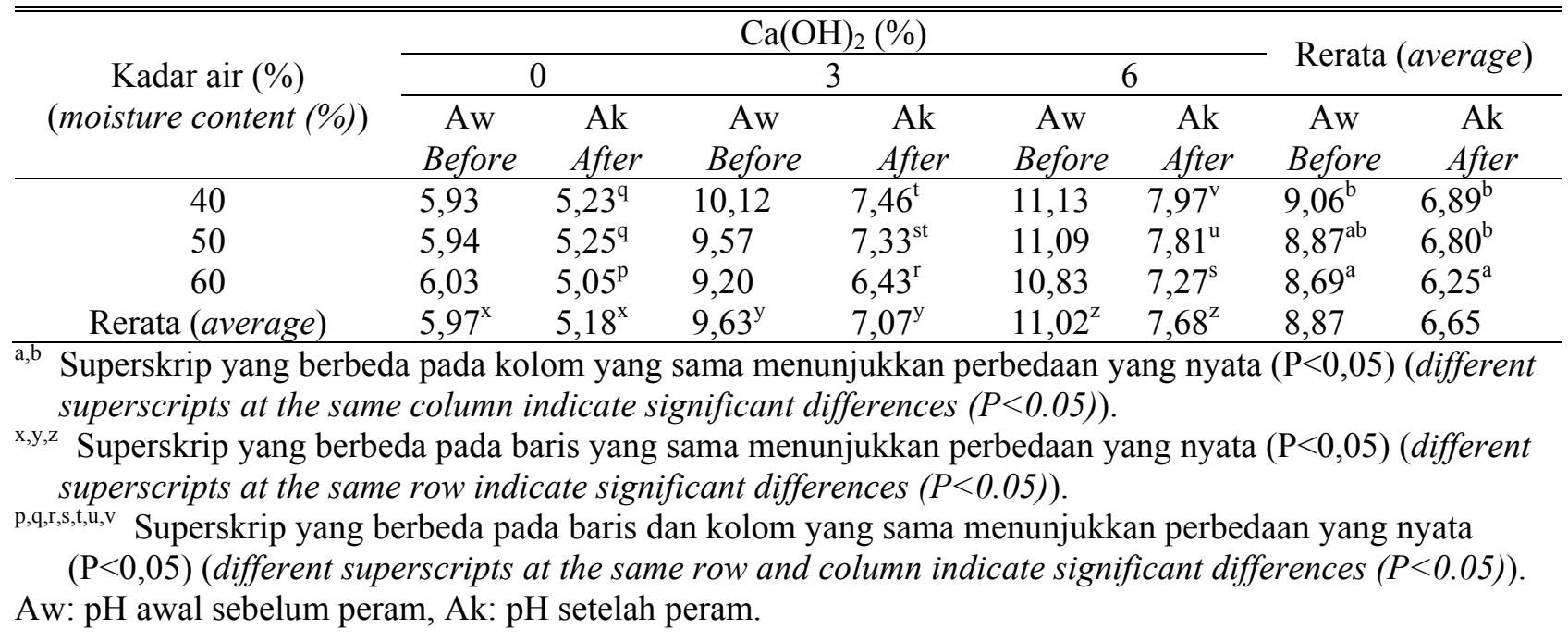

selama proses pemeraman berlangsung (Clayton et al., 2010). Penurunan kandungan BETN daun kelapa sawit kemungkinan disebabkan karena adanya pemanfaatan BETN oleh bakteri dan jamur pada saat pemeraman berlangsung dan adanya bahan-bahan organik terlarut, khususnya karbohidrat yang terlarut dalam air yang hilang bersama dengan tirisan (seepage) dari daun kelapa sawit akibat penambahan air pada awal perlakuan.

Terjadi penurunan NDF dengan semakin meningkatnya level $\mathrm{Ca}(\mathrm{OH})_{2}$, namun tidak pada kandungan ADF daun kelapa sawit. Penurunan kandungan NDF menunjukkan peningkatan isi sel. Penurunan NDF ini menunjukkan bahwa $\mathrm{Ca}(\mathrm{OH})_{2}$ melepaskan ikatan lignin dengan selulosa dan hemiselulosa. Hal ini sejalan dengan pernyataan Hadad et al. (1994) yang menyatakan bahwa $\mathrm{Ca}(\mathrm{OH})_{2}$ menurunkan kandungan NDF pada jerami gandum, namun kandungan ADF pada jerami gandum relatif sama pada level $\mathrm{Ca}(\mathrm{OH})_{2}$ yang berbeda. Hal ini dikarenakan ADF tidak merespon perlakuan alkali karena ADF mengandung komponen yang tahan terhadap perlakuan alkali. Namun, peningkatan kadar air bahan telah meningkatkan kandungan ADF daun kelapa sawit. Pada penelitian Caneque et al. (1998) menunjukkan bahwa peningkatan kadar air bahan akan meningkatkan kandungan ADF dari jerami barley yang diberi urea, yaitu 41,18, 42,96, dan 43,84\% pada masing-masing kadar air 20, 30, dan 40\%. Namun dibanding dengan daun kelapa sawit tanpa perlakuan, terjadi peningkatan kandungan NDF dan ADF dari daun kelapa sawit yang diberi perlakuan. Hal ini disebabkan karena penurunan dari karbohidrat non struktural selama proses pemeraman berlangsung (Seguin dan Mustafa, 2003).

\section{Kehilangan bahan organik daun kelapa sawit karena perlakuan}

Rerata kehilangan bahan organik daun kelapa sawit setelah perlakuan disajikan pada Tabel 5 . Kehilangan bahan organik pada daun kelapa sawit menunjukkan adanya bahan-bahan organik yang terlarut akibat penambahan air dan terjadinya fermentasi selama penyimpanan berlangsung. Utomo (2004) menyatakan bahwa selama proses fermentasi telah terjadi perombakan karbohidrat terstruktur dan karbohidrat non terstruktur yang terbukti oleh turunnya kadar bahan organik.

\section{Kecernaan}

Kecernaan bahan kering dan bahan organik daun kelapa sawit setelah perlakuan disajikan pada Tabel 6. Walaupun terjadi perubahan pada komposisi kimia daun kelapa sawit setelah perlakuan, namun tidak terjadi peningkatan kecernaan. Hal ini dapat disebabkan oleh beberapa faktor yaitu belum efektifnya perlakuan tunggal $\mathrm{Ca}(\mathrm{OH})_{2}$ pada daun kelapa sawit, level dan lama perlakuan $\mathrm{Ca}(\mathrm{OH})_{2}$, serta pengaruh pengeringan daun sebelum digunakan pada penelitian.

Belum efektifnya perlakuan $\mathrm{Ca}(\mathrm{OH})_{2}$ pada daun kelapa sawit pada penelitian ini disebabkan karena daun hanya dipotong secara manual sehingga $\mathrm{Ca}(\mathrm{OH})_{2}$ tidak dapat optimal bereaksi pada daun kelapa sawit. Mathius (2008) menyatakan bahwa pemanfaatan daun kelapa sawit sebagai pakan memiliki kelemahan, yaitu adanya lidi sehingga mengganggu ternak mengkonsumsinya. Masalah tersebut dapat diatasi dengan pencacahan. Pencacahan merupakan perlakuan fisik yang dapat dilakukan pada limbah sawit agar ukuran menjadi lebih kecil sehingga layak dikonsumsi ternak (Mathius et al., 2003 cit. Rohaeni, 2009). 


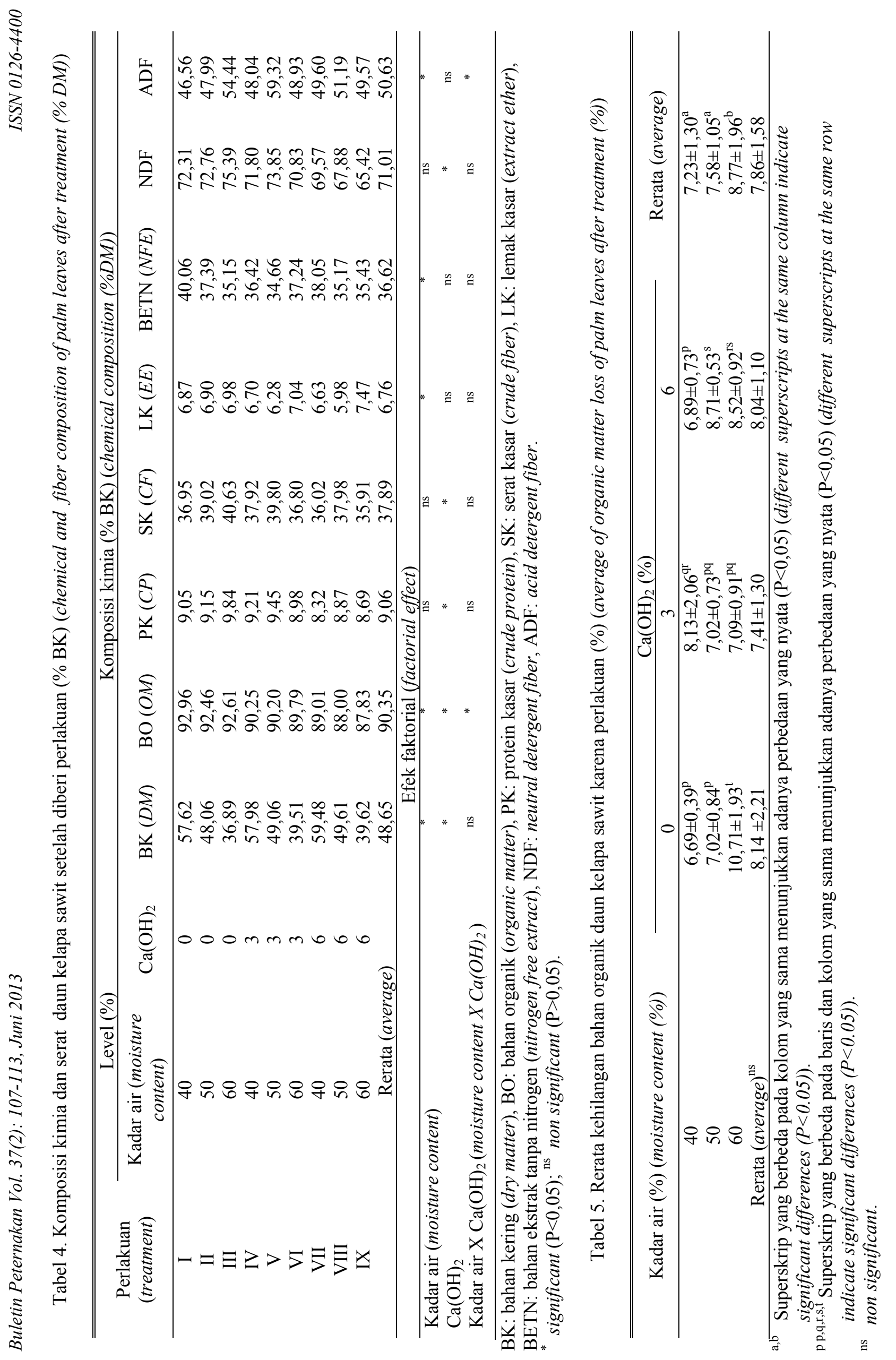


Tabel 6. Kecernaan in vitro daun kelapa sawit sesudah perlakuan (in vitro digestibility of palm leaves after treatment)

\begin{tabular}{|c|c|c|c|c|}
\hline \multirow{2}{*}{$\begin{array}{l}\text { Perlakuan } \\
\text { (treatment) }\end{array}$} & \multirow{2}{*}{$\begin{array}{c}\text { Kadar air }(\%) \\
\text { (moisture content }(\%) \text { ) }\end{array}$} & \multirow{2}{*}{$\begin{array}{l}\text { Level } \mathrm{Ca}(\mathrm{OH})_{2}(\%) \\
\left(\mathrm{Ca}(\mathrm{OH})_{2} \text { levels }(\%)\right)\end{array}$} & \multicolumn{2}{|c|}{ Kecernaan (\%) (digestibility (\%)) } \\
\hline & & & $\mathrm{KcBK}(D M D)$ & $\mathrm{KcBO}(O M D)$ \\
\hline I & 40 & 0 & 25,54 & 25,68 \\
\hline II & 50 & 0 & 23,78 & 24,34 \\
\hline III & 60 & 0 & 19,26 & 19,91 \\
\hline IV & 40 & 3 & 25,51 & 24,98 \\
\hline $\mathrm{V}$ & 50 & 3 & 25,97 & 26,21 \\
\hline VI & 60 & 3 & 24,49 & 24,71 \\
\hline VII & 40 & 6 & 29,55 & 28,26 \\
\hline VIII & 50 & 6 & 27,74 & 27,46 \\
\hline IX & 60 & 6 & 25,46 & 25,68 \\
\hline \multicolumn{3}{|c|}{ Rerata (average) } & 25,26 & 25,39 \\
\hline \multicolumn{5}{|c|}{ Efek faktorial (factorial effect) } \\
\hline \multicolumn{3}{|c|}{ Kadar air (moisture content) } & * & * \\
\hline \multicolumn{3}{|c|}{$\mathrm{Ca}(\mathrm{OH})_{2}$} & $*$ & $*$ \\
\hline \multicolumn{3}{|c|}{ Kadar air $\mathrm{X} \mathrm{Ca}(\mathrm{OH})_{2}$ (moisture content $\left.\mathrm{X} \mathrm{Ca}(\mathrm{OH})_{2}\right)$} & ns & $*$ \\
\hline
\end{tabular}

KcBK: kecernaan bahan kering (dry matter digestibility), KcBO: kecernaan bahan organik (organic matter digestibility).

* signifikan $(\mathrm{P}<0,05)$ (significant $(P<0.05))$.

${ }^{\text {ns }}$ non significant $(\mathrm{P}>0,05)$.

Kalsium hidroksida atau $\mathrm{Ca}(\mathrm{OH})_{2}$ merupakan basa lemah dibandingkan dengan $\mathrm{NaOH}$ dan keefektivannya ditentukan oleh kondisi perlakuan (Owen et al., 1984). Agar perlakuan $\mathrm{Ca}(\mathrm{OH})_{2}$ menjadi lebih efektif dibutuhkan waktu bereaksi yang lebih lama dan dosis yang lebih tinggi (Trach et al., 2001). Pada penelitian ini digunakan level $\mathrm{Ca}(\mathrm{OH})_{2}$ sebesar 3 dan $6 \%$ dengan waktu perlakuan 21 hari yang kemungkinan belum efektif untuk daun kelapa sawit. Walaupun telah terjadi perubahan komposisi kimia, namun untuk meningkatkan kecernaan dibutuhkan level yang lebih tinggi dan waktu perlakuan yang lebih lama.

Perubahan komposisi kimia daun kelapa sawit setelah diberi perlakuan turut pula mempengaruhi kecernaan daun kelapa sawit. Salah satunya adalah pada kandungan lemak kasar. Byers dan Schelling (1988) menyatakan bahwa lemak menurunkan digesti serat, salah satunya melalui proses pelapisan serat. Hal ini menyebabkan mikrobia rumen tidak dapat menyerang serat. Terlepasnya senyawa-senyawa phenolik dari ikatan dengan lignin pada daun kelapa sawit akibat penambahan $\mathrm{Ca}(\mathrm{OH})_{2}$ dapat pula mempengaruhi kecernaan karena senyawa-senyawa ini mempengaruhi aktivitas mikrobia rumen dalam mendegradasi komponen BK. Burrit et al. (1984) menyatakan bahwa senyawa phenolik memiliki korelasi dengan kecernaan bahan kering secara in vitro. Semakin meningkat konsentrasi senyawa phenolik, kecernaan bahan kering semakin rendah.
Menurut Sudaryanto et al. (1999) kecernaan bahan kering in vitro dari daun kelapa sawit dan lidi yang berasal dari tanaman kelapa sawit yang berumur lebih dari 10-15 tahun adalah $24,52 \%$ dan $3,80 \%$. Islam et al. (2000) menyatakan kecernaan bahan kering in vitro daun kelapa sawit tanpa lidi pada 48 jam adalah $38,42 \%$. Rerata nilai kecernaan bahan kering in vitro daun kelapa sawit pada penelitian ini berkisar antara 19,29-27,74\%. Selain faktor-faktor yang telah disebutkan di atas, perbedaan nilai kecernaan dari daun kelapa sawit pada penelitian ini dengan literatur yang ada kemungkinan disebabkan karena varietas dan umur tanaman kelapa sawit yang digunakan, bagian daun yang digunakan, komposisi kimia daun kelapa sawit, dan perlakuan yang diberikan. Ranjhan (1981) dan Crowder dan Chheda (1982) menyatakan bahwa faktor-faktor yang mempengaruhi kecernaan, antara lain bagian tanaman, tingkat pertumbuhan dan genotip, tingkat kedewasaan (stage of maturity), iklim, ukuran partikel, dan prosesing pakan.

\section{Kesimpulan}

Perlakuan dengan level kadar air dan $\mathrm{Ca}(\mathrm{OH})_{2}$ masing-masing mempengaruhi komposisi kimia daun kelapa sawit, tetapi tidak pada kecernaannya. Waktu perlakuan yang singkat, dan level yang rendah menyebabkan efektivitas perlakuan $\mathrm{Ca}(\mathrm{OH})_{2}$ pada daun kelapa sawit masih 
rendah. $\mathrm{Ca}(\mathrm{OH})_{2}$ dengan level $6 \%$ dengan kadar air $40 \%$ menunjukkan hasil terbaik pada penelitian ini.

\section{Daftar Pustaka}

AOAC. 2005. Official Method of Analysis of the Association of Official Analitycal Chemists. $12^{\text {th }}$ ed. Benjamin Franklin Station. Washington. Pp. 129-137.

Burrit, E. A., A. S. Bittner, J. C. Street and M. J. Anderson. 1984. Correlation of phenolic acids and xylose content of cell wall with in vitro dry matter digestibility of three maturing grasses. J. Dairy Sci. 67: 12091213.

Byers, F. M. and G. T. Schelling. 1988. Lipids in ruminant nutrition. In : The Ruminant Animal Digestive, Physiology and Nutrition. D. C. Church (ed). Prentice Hall, New Jersey.

Caneque, V., S. Velasco, J. L. Sancha, C. Manzanares and O. Souza. 1998. Effect of moisture and temperature on the degradability of fiber and on nitrogen fractions in barley straw treated with urea. Animal Feed Science and Technology 74: 241-258.

Clayton, E. H., P. C. Wynn, R. J. Mailer and J. W. Piltz. 2010. Total lipid and fatty acid profiles in fresh and ensiled forages grown in Australia. Proc. Aust. Soc. Anim. Prod. 28: 56.

Crowder, L. V. and H. R. Chheda. 1982. Tropical Grassland Husbandry. Longman Inc., New York.

Granzin, B. C. and G. McL. Dryden. 2003. Effects of alkalis, oxidants and urea on the nutritive value of rhodes grass (Chloris gayana cv. Callide). Animal Feed Science and Techology 103: 113-122.

Hadad, S. G., R. J. Grant and T. J. Klopfenstein. 1994. Digestibility of alkali - treated wheat straw measured in vitro or in vivo using Holstein heifers. J. Anim. Sci. 72: 3258-3265.

Harris, L. E. 1970. Chemical and Biological Methods for Feed Analysis. Center for Tropical Agric. Feed Composition Project. Livestock Pavillion University of Florida, Gainesville Florida.

Islam, M., I. Dahlan, M. A. Rajion and Z. A. Jelan. 2000. Productivity and nutritive value of different fractions of oil palm (Elaeis guineensis) frond. Asian-Aus. J. Anim. Sci. 13: 1113-1120.

Mathius, I. W. 2008. Pengembangan sapi potong berbasis industri kelapa sawit. Pengembangan Inovasi Pertanian 1: 206-224.
Owen, E., T. Klopfenstein and N. A. Urio. 1984. Treatment with other chemicals. In : Straw and other Fibrous By-Products as Feed. F. Sundstol and E. Owen (eds). Elsevier, New York.

Ranjhan, S. K. 1981. Animal Nutrition in Tropics. $2^{\text {nd }}$ ed. Vikas Publishing House PVT LTD, New Delhi.

Rohaeni, E. S. 2009. Potensi limbah sawit untuk pakan ternak sapi di Kalimantan Selatan. Available at http://peternakan.litbang. deptan.go.id/publikasi/lokakarya/lhmt05-

23.pdf. Accession date: 28 September, 2009.

Seguin, P. and A. F. Mustafa. 2003. Chemical composition and ruminal nutrient degradabilities of fresh and ensiled Kura clover (Trifolium ambiguum). Can. J. Anim. Sci. 83: 577-581.

Soejono, M. 1992. Aplikasi bioteknologi di bidang pakan dan nutrisi ternak. Buletin Peternakan Edisi Khusus: 57-65.

Steel, R. G. D. dan J. H. Torrie. 1993. Prinsip dan Prosedur Statistika. Suatu Pendekatan Biometrik. Edisi Kedua. PT. Gramedia Pustaka Utama, Jakarta.

Sudaryanto, B., K. Sumanto, dan Abdurrachman. 1999. Nilai kecernaan in vitro bagian daun kelapa sawit dari berbagai umur tanaman. Kumpulan makalah utama dan abstrak seminar nasional 'Peternakan mandiri sebagai penggerak pembangunan pertanian nasional'. Lustrum VI. Fakultas Peternakan, Universitas Gadjah Mada, Yogyakarta (Abstrak).

Trach, N. X., M. Mo and C. X. Dan. 2001. Effects of treatment of rice straw with lime and/or urea on its chemical composition, in-vitro gas production and in-sacco degradation characteristics. Available at http://www.lrrd. org/lrrd//rrd13/4/trac134a.htm. Accession date: September 28, 2009.

Utomo, R. 2004. Pengaruh penggunaan jerami padi fermentasi sebagai bahan dasar pembuatan pakan komplit pada kinerja domba. Buletin Peternakan 28: 162-171.

Utomo, R. 2010. Modifikasi metode penetapan kecernaan in vitro bahan kering atau bahan organik. Buletin Sintesis 15: 1-11.

Van Soest, P. J. 1994. Nutritional Ecology of the Ruminant. Second edition. Comstock Publishing Associate. Cornell University Press. 